\title{
INDUCTION OF RESIISTANCE IN TOMATO PLANTS AGAINST ROOT-KNOT NEMATODE BY SOME CHEMICAL AND PLANTS EXTRACTS ${ }^{(a)}$
}

\author{
Mostafa $^{1}$, M.H.; E.A.M. Gado ${ }^{1}$ and M.M. Youssef ${ }^{1}$ \\ 1- Laboratory Molecular Plant Pathology, Department Plant Pathology, Faculty of Agriculture, \\ Ain Shams University, Shoubra El-Kheima, Cairo, Egypt
}

Keywords: Tomato, Meloidogyne incognita, Sincocin and Agrispon, Ethyl salicylic acid and Jassmonic acids, Mango Malformed

\begin{abstract}
Different agents were tested as inducing resistance factors in tomato plants against root-knot nematode Meloidogyne incognita. These agents include ethyl salicylic acid, $(0.125 \mathrm{ml} / \mathrm{l})$ jassmonic acid $(0.125 \mathrm{ml} / \mathrm{L})$ sincocin solution, (0.1\%) agrispon solution $(0.1 \%)$ water extract of mango malformed inflorescence (7.5\%), coconut milk solution $(2 \%)$ as root dipping during transplanting and spraying after one month from transplanting. Data obtained clearly indicated that sincocin solution, extract of mango malformed inflorescence, agrispon solution and jassmonic acid led to a great reduction in disease severity, number of galls/ root, number of females/ root and number of egg masses/ root, followed by ethyl salicylic acid and coconut milk descending order. All tested agents did not affect juvenile's viability except mango malformed inflorescence extract and coco-nut milk solution which led to slight effect on juvenile viability. All tested agents increased plant growth in the presence of nematode inocula in comparison to untreated plants. In this respect coconut milk solution had the superior effect. Data indicated that the tested agents induced resistance in treated plant and the mechanisms of their mode of action needs further studies.
\end{abstract}

\section{INTRODUCTION}

Root-knot nematodes on tomato causing by Meloidogyne spp. are widely distributed all over the world (Sasser, 1980) and in Egypt (Shawadfy and Mousa, 1997). These nematodes can cause the formation of galls that distort the roots and reduce water and nutrient uptake and may facilitate secondary infection by soil born fungi, i.e Fusarium vascular wilt (Kassab and Ali, 1995).

Many trials were carried out to manage rootknot nematodes varied from soil solarization (Ioannou, 2000), and soil amendments (Mankau and Das 1974; Badra et al 1979; Derrico and Maio 1980; Godoy et al 1983 and Natarajan et al 2006).

Induction of systemic acquired resistance in plants became widespread nowadays to manage broad range of plant pathogens including bacteria, viruses, fungi and some insects (Sticher et al 1997) by application of many chemical compounds, i.e., salicylic acid or its derivatives (Dean and Kuc, 1987 and Molinari and Loffredo, 2006).

Recently, plant extracts were found to induce resistance in plants (Hendy et al 1994 and Daay et al 1995).

The present study was aimed to investigate the effects of some chemical compounds and plant extracts as inducing resistance agents against rootknot nematode in tomato plants.

\section{MATERIALS AND METHODS}

\section{Plants and cultivar}

Tomato seeds Lycopersicom esculentum cv. supermarmand (susceptible cultivar to root-knot nematode) were cultivated into foam trys contained beet moss and vermiculate $(1: 1 \mathrm{v} / \mathrm{v})$. Seedlings were taken after 45 days from sowing.

a. This work was financially supported by Academy of Scientific Research and Technology, Egypt

(Received October 16, 2006)

(Accepted November 27, 2006) 


\section{Agents and treatments}

The chemical agents used in this study were ethylsalicylic acid (ESA $0.125 \mathrm{ml} / \mathrm{L}$ ) and jassmonic acid (JAS $0.125 \mathrm{ml} / \mathrm{L}$ ). Plant extract agents were : water extract of mango malformation inflorescence (ME $75 \mathrm{~g} / \mathrm{L}$ ) coconut milk (CMO $20 \mathrm{ml} / \mathrm{L}$ ), and water solutions of commercial products of $\operatorname{sincocin}^{\circledR}(\mathrm{SIN} 1 \mathrm{ml} / \mathrm{L})$ or agrispon $^{\circledR}$ (AGR $1 \mathrm{ml} / \mathrm{L}$ ) water solutions. Extracts and commercial products were freshly prepared, then root seedling were dipped into water solutions of the previously mentioned factors for two hours then transplanted in clay pots $(30 \mathrm{~cm}$ in diameter) contained stream sterilized sandy loam soil $(1: 1 \mathrm{v} / \mathrm{v})$. One seedling was transplanted / pot and 20 pots were used for each treatment.

After 30 days from inoculation, plants were sprayed by tested agents. Spraying was carried out using hand atomizer till the drops run off.

\section{Pots inoculation}

In all treatments, each pot was inoculated with 1000 newly hatched second-stage juvenile of Meloidogyne incognita. Sherwood. Inoculation was made at 8 days after transplanting, into four holes around the plant base. After the inoculation, the holes were closed by pressing the soil then pots were irrigated.

Determination of diseases incidence and developmental stages of Meloidogyne incognita in treated tomato roots

Disease severity was determined after 45 days from inoculation by root-knot nematode. Disease was estimated on an arbitrary scale ranged from 0 to 5 as described by Hussey and Boerma (1981), where $0=$ no galling, $1=$ trace infection with a few small galls, $2=<25 \%$ roots galled, $3=25$ $50 \%$ roots galled, $4=51-75 \%$ roots galled and 5 $=77.5 \%$ of roots galled.

For determination of developmental stages, i.e., number of galls/ root, number of egg-mass / root and, number of mature females / root, the roots of each plant were stained with lactophenol acid fuchsin then developmental stages were counted. All these parameters were determined 45 days from transplanting. Two distict experiments were carried out.

Effect of tested agents on survival of second juveniles the stage of of $M$. incognita

Juveniles of the second juvenile stages of $M$. incognita were mixed with water solutions of the tested agents by a rate of 100 juveniles / $\mathrm{ml}$ in epindorff tubes. Tubes were incubated at room temperature $\left(18-22^{\circ} \mathrm{C}\right)$ for $24 \mathrm{~h}$. Number of survival and dead juveniles were counted under light microscope using slide of counting nematodes. In control treatment juveniles were added to distilled water.

\section{Determination of vegetative growth of treated tomato plants}

Plant heights, dry and wet foliage weight were determined after 45days from transplanting.

\section{Statistical analysis}

The data were statistically analyzed by analysis of variance (ANOVA), by using statistical Analysis System (SAS) followed by Duncan's multiple range test $(\mathrm{P} \leq 0.05)$ (Duncan, 1955).

\section{RESULTS}

\section{Disease incidence parameters}

\section{a. Disease severity}

Disease severity was calculated according to linear scale ranged form 0 to 5 . Data tabulated in Table (1) clearly indicate the presence of significant difference between all treatments and control one and superior effect was obtained with SIN and ME followed by AGR and JAS in equal effect then COM solution. The least effect was obtained from COM treatment. This trend of results was found in both experiments. By calculation the efficiency of the treatment, it could say that sincocin and (ME) extract were the best treatment, followed by JAS and AGR in equal values. The least effective extract was COM solution.

\section{b. Number of galls/ root}

Number of galls/ plant, as indicate in Table (2) greatly reduced due to the treatment with sincocin, mango malformation extract or agrispon in both experiments followed by jassmonic acid treatment. Minimum effect was obtained by coconut milk solution treatment, as it gave the least efficient value (19.3) comparing to check, in comparison with $60 \%$ efficiency in case of sincocin treatment. 
Table 1. Effect of treatment by different agents on disease severity of root-knot nematode in inoculated plants

\begin{tabular}{|ccccc|}
\hline \multirow{2}{*}{ Treatments } & \multicolumn{4}{c|}{ Disease severity } \\
\cline { 2 - 5 } & Exp1 & Exp2 & Mean & $\begin{array}{c}\text { Effectiveness } \\
\% *\end{array}$ \\
\hline ESA & $2.5^{\mathrm{c}}$ & $2^{\mathrm{c}}$ & 2.25 & 38.3 \\
JAS & $1.7^{\text {abd }}$ & $1.8^{\text {ad }}$ & 1.75 & 52 \\
COM & $3^{\mathrm{b}}$ & $3.2^{\mathrm{b}}$ & 3.1 & 15 \\
ME & $1.8^{\text {ad }}$ & $1.6^{\text {abd }}$ & 1.7 & 53.4 \\
SIN & $1.9^{\text {ad }}$ & $1.5^{\text {abcd }}$ & 1.7 & 53.4 \\
AGR & $1.7^{\text {abd }}$ & $1.8^{\text {ad }}$ & 1.75 & 52 \\
CON & $3.7^{\text {a }}$ & $3.8^{\text {a }}$ & 3.75 & 0 \\
\hline
\end{tabular}

Ethyl Salicylic acid (ESA $0.125 \mathrm{ml} / \mathrm{L})$

Jassmonic acid (JAS $0.125 \mathrm{ml} / \mathrm{L}$ ).

Coconut milk (COM $20 \mathrm{ml} / \mathrm{L}$ )

Mango malformations extract (ME $75 \mathrm{~g} / \mathrm{L}$ )

$\operatorname{Sincocin}^{\circledR}($ SIN $1 \mathrm{ml} / \mathrm{L})$

Agrispon ${ }^{\circledR}$ (AGR $\left.1 \mathrm{ml} / \mathrm{L}\right)$

Non-treated control $(\mathrm{CON})$

Means of treatments within the same row with different superscript letters are differ $(\mathrm{p}<0.05)$

Effectiveness were calculated according to the following formula

Reading in the control-reading in the treatment Effectiveness \% =

Reading in the control $X 100$

Table 2. Effect of treatments of tomato plants with different agents on number of galls/plant

\begin{tabular}{|ccccc|}
\hline \multirow{3}{*}{ Treatments } & \multicolumn{4}{c|}{ Number of galls/ plant } \\
\cline { 2 - 5 } & Exp1 & Exp2 & Mean & $\begin{array}{c}\text { Effectiveness } \\
\%\end{array}$ \\
\hline ESA & $37.1^{\mathrm{c}}$ & $32.2^{\mathrm{c}}$ & 34.2 & 40.3 \\
JAS & $25.1^{\mathrm{d}}$ & $27.3^{\mathrm{d}}$ & 26.2 & 54.8 \\
COM & $45.7^{\mathrm{b}}$ & $48^{\mathrm{b}}$ & 46.8 & 19.3 \\
ME & $27^{\mathrm{d}}$ & $22.6^{\mathrm{e}}$ & 24.8 & 57.2 \\
SIN & $26^{\mathrm{d}}$ & $19.5^{\mathrm{h}}$ & 22.7 & 60.9 \\
AGR & $20.2^{\mathrm{e}}$ & $27.1^{\mathrm{d}}$ & 23.5 & 59.5 \\
CON & $55.8^{\mathrm{a}}$ & $60.2^{\mathrm{a}}$ & 58 & 0 \\
\hline
\end{tabular}

Ethyl Salicylic acid (ESA $0.125 \mathrm{ml} / \mathrm{L}$ )

Jassmonic acid (JAS $0.125 \mathrm{ml} / \mathrm{L}$ ).

Coconut milk (COM $20 \mathrm{ml} / \mathrm{L}$ )

Mango malformations extract (ME $75 \mathrm{~g} / \mathrm{L}$ )

Sincocin $^{\circledR}(\mathrm{SIN} 1 \mathrm{ml} / \mathrm{L})$ Agrispon $^{\circledR}$

(AGR $1 \mathrm{ml} / \mathrm{L}$ )

Non-treated control (CON)

Means of treatments within the same row with different superscript letters are differ $(\mathrm{p}<0.05)$.

\section{c. Number of egg mass/ root}

Number of egg masses/plant was determined in root plants treated by chemical or water plant extracts and inoculated by root-knot nematode. Data presented in Table (3) indicated clearly that sincocin is effective in reducing number of galls / plant root. It decreased such number from 85.9 (average of two experiment) to 30 galls/ root. Coconut milk gave the least effect with average efficiency reaching $29.5 \%$. Jassmonic acid gave also good result as give SIN. Mango malformations extract was also very effective in this respect.

Table 3. Effect of treatment of tomato plants with different agents on number of egg masses / plant

\begin{tabular}{|ccccc|}
\hline \multirow{2}{*}{ Treatments } & \multicolumn{4}{c|}{ Number of egg mass/plant } \\
\cline { 2 - 5 } & Exp1 & Exp2 & Mean & $\begin{array}{c}\text { Effectiveness } \\
\%\end{array}$ \\
\hline ESA & $47^{\mathrm{c}}$ & $50.5^{\mathrm{c}}$ & 48.7 & 43.2 \\
JAS & $28.2^{\mathrm{d}}$ & $33.9^{\mathrm{e}}$ & 31 & 63.8 \\
COM & $59.1^{\mathrm{b}}$ & $62^{\mathrm{b}}$ & 60.5 & 29.5 \\
ME & $30.9^{\mathrm{d}}$ & $34.5^{\mathrm{e}}$ & 32.7 & 62 \\
SIN & $29^{\mathrm{d}}$ & $31^{\mathrm{h}}$ & 30 & 65 \\
AGR & $45.2^{\mathrm{c}}$ & $46.5^{\mathrm{d}}$ & 45.8 & 46.6 \\
CON & $84^{\mathrm{a}}$ & $87.8^{\mathrm{a}}$ & 85.9 & 0 \\
\hline
\end{tabular}

Ethyl Salicylic acid (ESA $0.125 \mathrm{ml} / \mathrm{L}$ )

Jassmonic acid (JAS $0.125 \mathrm{ml} / \mathrm{L}$ ).

Coconut milk (COM $20 \mathrm{ml} / \mathrm{L}$ )

Mango malformations extract (ME $75 \mathrm{~g} / \mathrm{L}$ )

Sincocin ${ }^{\circledR}(\operatorname{SIN~} 1 \mathrm{ml} / \mathrm{L})$

Agrispon $^{\circledR}($ AGR $1 \mathrm{ml} / \mathrm{L})$

Non-treated control (CON)

Means of treatments within the same row with different superscript letters are differ $(\mathrm{p}<0.05)$.

\section{d. Average number of mature females/ root}

Average number of mature female (Table 4) clearly indicate that all treatment reduced such number. The most effective one is sincocin followed by $\mathrm{ME}$; they reduced number of mature females from 180.2 in check to 45.8 and 57.6 respectively. Moderate effects were obtained with JAS followed by ESA acid, AGR and COM in descending order. 
Table 4. Effect of treatment of tomato plants with different agents on number of mature females/plant

\begin{tabular}{|ccccc|}
\hline \multirow{2}{*}{ Treatments } & \multicolumn{4}{c|}{ Number of mature female /plant } \\
\cline { 2 - 5 } & Exp1 & Exp2 & Mean & $\begin{array}{c}\text { Effectiveness } \\
\%\end{array}$ \\
\hline ESA & $84.7^{\mathrm{d}}$ & $90.5^{\mathrm{b}}$ & 87.6 & 51.4 \\
JAS & $75^{\mathrm{e}}$ & $81^{\mathrm{c}}$ & 78 & 56.7 \\
COM & $104.5^{\mathrm{b}}$ & $80.2^{\mathrm{c}}$ & 92.3 & 48.8 \\
ME & $60.3^{\mathrm{h}}$ & $55^{\mathrm{e}}$ & 57.6 & 68 \\
SIN & $50^{\mathrm{f}}$ & $41.6^{\mathrm{h}}$ & 45.8 & 74.6 \\
AGR & $89.5^{\mathrm{c}}$ & $78^{\mathrm{d}}$ & 83.6 & 53.6 \\
CON & $170.5^{\mathrm{a}}$ & $190^{\mathrm{a}}$ & 180.2 & 0 \\
\hline
\end{tabular}

Ethyl Salicylic acid (ESA $0.125 \mathrm{ml} / \mathrm{L}$ )

Jassmonic acid (JAS $0.125 \mathrm{ml} / \mathrm{L}$ ).

Coconut milk (COM $20 \mathrm{ml} / \mathrm{L}$ )

Mango malformations extract (ME $75 \mathrm{~g} / \mathrm{L}$ )

Sincocin $^{\circledR}(\operatorname{SIN} 1 \mathrm{ml} / \mathrm{L})$

Agrispon ${ }^{\circledR}$ (AGR $1 \mathrm{ml} / \mathrm{L}$ )

Non-treated control $(\mathrm{CON})$

Means of treatments within the same row with different superscript letters are differ $(\mathrm{p}<0.05)$

The effect of chemical and plant extracts on viability of second stage juveniles of $M$. incognita

The effect of mixing water solutions of two chemical compounds (i.e. ethyl salicylic acid and jassmonic acid) and four plant extracts (i.e. coconut milk, water extract of mango information inflorescence (ME), solution of sincocin and solution of agrispon) on viability or mortality of newly second stage juveniles of $M$. incognita after $24 \mathrm{~h}$ from exposure of the juveniles to the tested agents was carried out.

Data represented in Table (5) clearly indicated that all tested agents except ME extract had no effect on juveniles viability. Mango malformations extract have a weak effect on juveniles viability whereas, it caused average mortality reached $27.5 \%$.

\section{Vegetative growth of tomato plants}

Under the influence of inoculation by root-knot nematode ( $M$. incognita) and treatment by chemical and natural plant extract, the vegetative growth parameters i.e. plant height, foliage fresh weight, foliage dry weight were determined. Data in Table (6) and Fig. (1) clearly indicate that all treatment led to a significant increase of all mentioned parameters. Coconut milk, agrispon and ME gave the best results in this respect. Surprisingly, coconut milk treatment gave superior results it approximately duplicate plant height and foliage weight in comparison to other treatments.

Table 5. Effect of different agents on juveniles' viability after $24 \mathrm{~h}$ from incubation at root temperature (18-22).

\begin{tabular}{|cccc|}
\hline \multirow{2}{*}{ Treatments } & \multicolumn{3}{c|}{ Survival juveniles } \\
\cline { 2 - 4 } & Exp1 & Exp2 & Mean \\
\hline ESA & 97 & 95 & 96 \\
JAS & 94 & 97 & 95.5 \\
COM & 85 & 79 & 82 \\
ME & 75 & 70 & 72.5 \\
SIN & 98 & 97 & 97.5 \\
AGR & 99 & 97 & 98 \\
CON & 99 & 98 & 98.5 \\
\hline
\end{tabular}

Ethyl Salicylic acid (ESA $0.125 \mathrm{ml} / \mathrm{L}$ )

Jassmonic acid (JAS $0.125 \mathrm{ml} / \mathrm{L}$ )

Coconut milk (COM $20 \mathrm{ml} / \mathrm{L}$ )

Mango malformations extract (ME $75 \mathrm{~g} / \mathrm{L}$ )

Sincocin $^{\circledR}(\operatorname{SIN} 1 \mathrm{ml} / \mathrm{L})$

Agrispon $^{\circledR}$ (AGR $\left.1 \mathrm{ml} / \mathrm{L}\right)$

Non-treated control $(\mathrm{CON})$

\section{DISCUSSION}

Different trails were carried out to induce resistance in plants against nematode infection. Owen et al (2002) found that benzothiadiazole (BTH) caused a significant reduction in egg deposition by root-knot nematodes of grapevines. They found that BTH treatment led to increase of $\beta-1,3$ glucanase activity in treated plants.

Glazer and Orion (1985) have tested hydroxyurea as soil drench for inducing resistant agent in tomato plants against root-knot nematode Meloidogyne javanica. Their results indicated that number of females on the root was reduced. Some amino acid as foliar spray, were found to enhance resistance of tomato plants to root-knot nematode Meloidogyne incognita (Osman and Viglierchio, 1988).

In our previous study, we found that some plant extract enhance peroxidase activity in potato tuber slices (Mostafa, et al unpublished data). Among these extracts, mango inflorescence 
Table 6. Effect of treatment of tomato plants with different agents on vegetative growth of plants under influence of inoculation with $M$. incognita

\begin{tabular}{|cccccccccc|}
\hline \multirow{2}{*}{ Treatments } & \multicolumn{3}{c}{ Plant height $(\mathrm{cm})$} & \multicolumn{3}{c}{ Foliage weight $(\mathrm{g})$} & \multicolumn{3}{c|}{ Foliage dry weight $(\mathrm{mg})$} \\
\cline { 2 - 10 } & Exp1 & Exp2 & Mean & Exp1 & Exp2 & Mean & Exp1 & Exp2 & Mean \\
\hline ESA & $20.5^{\mathrm{e}}$ & $18^{\mathrm{e}}$ & 19.2 & $8.85^{\mathrm{d}}$ & $11^{\mathrm{eh}}$ & 9.9 & $870^{\mathrm{f}}$ & $920^{\text {af }}$ & 895 \\
JAS & $24.8^{\text {cd }}$ & $20.5^{\mathrm{d}}$ & 22.6 & $11.8^{\mathrm{c}}$ & $12.5^{\mathrm{e}}$ & 12 & $1200^{\mathrm{e}}$ & $1350^{\mathrm{e}}$ & 1275 \\
COM & $39.5^{\mathrm{a}}$ & $25.4^{\mathrm{ab}}$ & 32.4 & $28.1^{\mathrm{a}}$ & $20^{\mathrm{b}}$ & 24 & $2800^{\mathrm{a}}$ & $2420^{\mathrm{a}}$ & 2610 \\
ME & $27.6^{\mathrm{b}}$ & $24.5^{\mathrm{c}}$ & 26 & $10.7^{\mathrm{bcd}}$ & $17.6^{\mathrm{c}}$ & 14 & $1500^{\mathrm{c}}$ & $2010^{\mathrm{c}}$ & 1754 \\
SIN & $17^{\text {ah }}$ & $19^{\text {ae }}$ & 18 & $14.7^{\mathrm{b}}$ & $20.9^{\mathrm{b}}$ & 17.8 & $1800^{\mathrm{b}}$ & $2225^{\mathrm{b}}$ & 2012 \\
AGR & $25.1^{\mathrm{c}}$ & $26^{\mathrm{a}}$ & 25.5 & $12.4^{\mathrm{c}}$ & $15.8^{\mathrm{d}}$ & 14.1 & $1350^{\mathrm{d}}$ & $1700^{\mathrm{d}}$ & 1500 \\
CON & $16.9^{\mathrm{h}}$ & $17.3^{\mathrm{h}}$ & 17.1 & $11.5^{\mathrm{ac}}$ & $10.7^{\text {aeh }}$ & 11.1 & $950^{\mathrm{h}}$ & $930^{\mathrm{f}}$ & 940 \\
\hline
\end{tabular}

Ethyl Salicylic acid (ESA $0.125 \mathrm{ml} / \mathrm{L})$

Jassmonic acid (JAS $0.125 \mathrm{ml} / \mathrm{L}$ ).

Coconut milk (COM $20 \mathrm{ml} / \mathrm{L})$

Mango malformations extract (ME $75 \mathrm{~g} / \mathrm{L})$

$\operatorname{Sincocin}^{\circledR}(\operatorname{SIN} 1 \mathrm{ml} / \mathrm{L})$

Agrispon ${ }^{\circledR}$ (AGR $\left.1 \mathrm{ml} / \mathrm{L}\right)$

Non-treated control (CON)

Means of treatments within the same row with different superscript letters are differ $(\mathrm{p}<0.05)$.

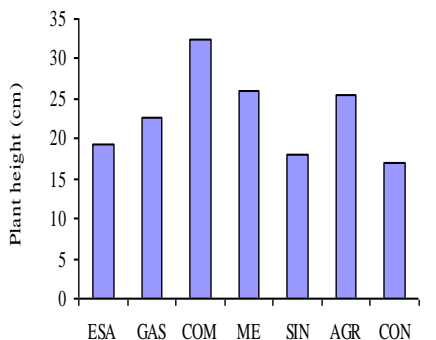

ESA GAS COM ME SIN AGR CON
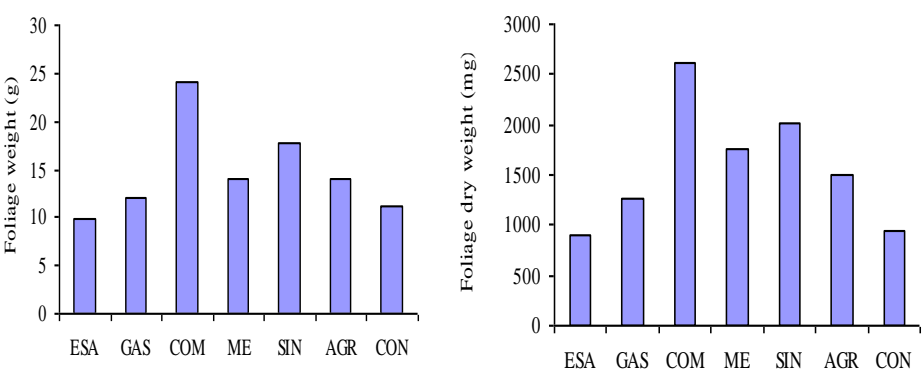

Fig. 6. Effect of treatment of tomato plants with different agents on vegetative growth of plants under influence of inoculation with $M$. incognita

Ethyl Salicylic acid (ESA $0.125 \mathrm{ml} / \mathrm{L})$

Coconut milk (COM $20 \mathrm{ml} / \mathrm{L})$

Sincocin ${ }^{\circledR}(\mathrm{SIN} \mathrm{ml} / \mathrm{L})$

Non-treated control (CON)
Jassmonic acid (JAS $0.125 \mathrm{ml} / \mathrm{L}$ ).

Mango malformations extract (ME $75 \mathrm{~g} / \mathrm{L}$ )

Agrispon $^{\circledR}($ AGR $1 \mathrm{ml} / \mathrm{L})$ 
malformation water extract, coconut milk solution, SIN and AGR. Ethyl salicylic and JAS was also found to increase peroxidase activity. Since peroxidase consider (Bajaj and Maiiajan 1977; Kaplan and Keen 1980; Premacliandrad and Dasguptad 1983 and Van Loon 1997) a marker of resistance in plants, we decided to test these agents as inducing resistance agents in tomato plants against root-knot nematode (Meloidogyne incognita).

Disease severity on tomato roots due to inoculation with $M$. incognita second stage juveniles under the influence of treatment tomato root and plants spray was determined. Data obtained in this study indicated that all tested agents reduced disease severity, number of galls/ plant, number of females/ plant and number of egg masses/ plant. The best results were obtained from SIN treatment. In this respect, Hendy et al (1994) have found that SIN $10 \%$ and $15 \%$ gave the highest reduction of Meloidogyne larvae and egg masses in tomato plants. Jassmonic acid and ESA have good results in reducing all parameters of $M$. incognita life cycle.

Oka et al (1999) have tested different chemical compounds as inducing resistant agents. They found that Dl- $\beta$-amino-n-butyric acid reduced root-galling 7 days after inoculation as well as the number of egg 30 days after inoculation. They found that other chemicals ( $\beta$ and $\gamma$ amino butyric acid, JAS, methyl jassmonate and salicylic acid) were either phytotoxic to tomato plants or did not improve control of root-knot nematodes.

Ethyl salicylic acid and JAS in the present investigation reduced disease severity, number of galls, number of egg mass to very great extent in comparison with control, no any phytotoxic effect was observed on treated plants. This may be due to the concentration used in this study was much diluted in comparison to the concentrations used by Oka et al 1993 and Molinari and Loffredo 2006.

To issue that the reducing of disease parameters due to the treatment with tested agents was reflected to inducing resistance, all agents were tested on juvenile's viability. All tested compounds did not affect juveniles' viability in comparison to the control except ME which led to reduction in viability by $22 \%$.

The obtained results greatly indicated that these tested compounds acted through inducing resistance agents except coconut milk. They induced resistance in treated tomato plants in various degrees. Sincocin and water extract of mango malformation inflorescence gave the best results as inducing resistance agents, followed by jassmonic acid and agrispon, then ethyl salicylic acid. The least results were obtained with coconut milk solution.

Concerning morphological feature, all tested agents led to a great enhancement of plant height, foliage fresh and dry weights. Coconut milk solution gave superior results in this respect. This effect may be due to that the active ingredient in coconut milk which serves as plant growth regulator is N-6-furfuryladenine (Bruce et al 1965). The mechanisms underlying inducing resistance in tomato plants against root-knot nematode by using the former compounds and agents need further investigation.

\section{REFERENCES}

Badra, T.; M.A. Saleh and B.A. Oteifa (1979). Nematicidal activity and composition of some organic fertilizers and amendments. Revue de Nematologie 2: 29-36.

Bajaj, K.L. and R. Maiiajan (1977). Phenolic compounds in tomato susceptible and resistant to Meloidogyne incognita (Kofoid \& White) Chitwood. Nematol. Medit. 5: 329-333.

Bruce, M.I.; J.A. Zwar and N.P. Kefford (1965). Chemical structure and plant kinin activity $:$ the activity of urea and thiourea derivatives. Life Science, 4: 461 - 466.

Daay, F.; A. Schmidt and R.R. Belonger (1995). The effects of plant extracts of Reynoutria sachalinensis on powdery mildew development and leaf physiology of long English cucumber. Plant Disease79: 577-580.

Dean, R.A. and J. Kuc (1987). Immunization against disease: The plant fights back, In: Fungal Infection of Plants (eds). pp. 383-410. Page, F. and P.G. Qyres, Cambridge Univ. Press, Cambridge, $428 \mathrm{pp}$.

Derrico, F.P. and F.D. Maio (1980). Effect of some organic materials on root-knot nematodes on tomato in field : preliminary experiments. Nematol. Medit. 8: 107-111.

Duncan, B. D.(1955). Multiple ranges and multiple F test. Biometric11: 1-42.

Glazer, C. and D. Orion (1985). An induced resistance of hydroxyura on plants infected by Meloidogyne javanica. J. Nematol. 17: 21-24.

Godoy, G.; R. Rodrlguez-Kbana; R.A. Shelby and G. Morgan-Jones (1983). Chitin amendments for control of Meloidogyne arenaria in in- 
fested soil. II. Effects on microbial population. Nematropica 13: 63-74.

Hendy, H.H.; H.I. El-Nagar; A.A. Osman and A.A. Farahat (1994). The roll of biological agents in regulating plant parasitic nematodes infecting tomato plants. Egyptian J. Applied Sci. 9: 215226.

Hussey, R.S. and H.R. Boerma (1981). Greenhouse procedure for screening for root-knot nematode resistance in soybeans. Crop Sci. 21: 794796.

Ioannou, I. (2000). Soil solarization as a substitute for methyl bromide fumigation in greenhouse tomato production in Cyprus. Phytoparasitica 28: 1-9.

Kaplan, D.T. and N.T. Keen (1980). Mechanisms conferring plant incompatibility to nematodes. Revue Nématol. 3: 123-134.

Kassab, A.S. and M.K. Ali (1995). Interaction of Meloidogyne incognita and Fusarium oxysporium F. sp. Lycopersici on a resistant tomato cultivar. Annals Agric Sci., Ain Shams Univ., Cairo, Egypt 40(2): 497-951.

Mankau, R. and S. Das (1974). Effect of organic materials on nematode bionomics in citrus and root-knot nematode infested field soil. Indian J. Nematol. 4: 138-151.

Molinari, S. and E. Loffredo (2006). The role of salicylic acid in defense response of tomato to root-knot nematodes. Physiol. Mol. Plant Pathol. 68: 69-78.

Natarajan, N.; A. Cork; N. Boomathi; R. Pandi; S. Velavan and G. Dhakshnamoorthy (2006). Cold aqueous extracts of African marigold, Tagetes erecta for control tomato root knot nematode, Meloidogyne incognita. Crop Protection 25: 1210-1213.
Oka, Y.; I. Chet and Y. Spiegel (1993). Control of root-knot nematode Meloidogyne javanica by Bacillus cereus. Biocontrol Sci. Technol. 3: 115126.

Oka, Y.; Y. Cohen and Y. Spiegel (1999). Local and Systemic induced resistance to the root knot nematode in tomato by DL- $\beta$-amino-n-Butyric acid. Phytopathology 89: 1138-1143.

Osman, A.A. and D.R. Viglierchio (1988). Efficacy of biologically active agents as nontraditional nematicides for Meloidogyne javanica. Revue Nématol. 11: 93-98.

Owen, K.J.; C.D. Green and B.J. Deveral (2002). A benzothiadiazole applied to foliage reduces development and egg deposition by Meloidogyne spp. in glasshouse-grown grapevine roots. Australian Plant Pathology 31: 47-53.

Premacliandrad, N. and R. Dasguptad (1983). Changes in nucleic acids and ribonuclease in tomato plants during infection by the root-knot nematode, Meloidogyne incognita. Revue Nématol. 6: 33-38.

Sasser, J.N. (1980). Root-knot nematodes: a global threat to crop production. Plant Dis. 64: 36-41. Shawadfy, M.M. and E.M. Mousa (1997). Biological management of soil-borne pathogens and root-knot nematode complexes on soybean. Proceedings of the First International Workshop of Afro-Asian Nematologists. pp. 7-27. Monoufiya University, Shebin El-Kom, Egypt.

Sticher, L.; B. MauchMani and J.P. Metraux (1997). Systemic acquired resistance. Annual Rev. Phytopathol. 35: 235-70.

Van Loon, L.C. (1997). Induced resistance in plants and the role of pathogenesis-related proteins. European J. of Plant Pathol. 103: 753765. 